\title{
EFFICACY OF SULFADIAZINE AND TRIMETHOPRIM FOR THE TREATMENT OF INFECTIOUS CORYZA AND ENROFLOXACIN FOR PULLORUM DISEASE IN COMMERCIAL LAYER BIRDS
}

\author{
M. A. H. Mondal ${ }^{1,3}$, M. M. Rahman ${ }^{2}$, M. M. U. Bhuiyan ${ }^{2}$, M. Shamsuddin ${ }^{2,4}$ and M. T. Islam ${ }^{1 *}$ \\ ${ }^{1}$ Department of Medicine, ${ }^{2}$ Community-based Dairy Veterinary Foundation, Department of Surgery and \\ Obstetrics, Bangladesh Agricultural University, Mymensingh-2202, Bangladesh; ${ }^{3}$ Doctors Poultry and Dairy \\ Lab, Aziz Fokir Market, Mawna, Sreepur, Gazipur, ${ }^{4}$ International Atomic Energy Agency, Austria, Vienna
}

\begin{abstract}
This study was conducted in the Bismillah Poultry Farm and Orkid Poultry Farm, Sreepur, Gazipur to evaluate efficacy of sulfadiazine and trimethoprim, and enrofloxacin against infectious coryza and pullorum disease in commercial layer birds. A total of 300 birds affected with infectious coryza in the Bismillah Poultry Farm were treated with two commercial preparations of sulfadiazine and trimethoprim, Ativet (Acme) and Trimsul 80/400 (DutchFarm). Four hundred birds affected with pullorum disease in the Orkid Poultry Farm were treated with two commercial preparations of enrofloxacin, Enrovet (Acme) and Komibiotril (Komipharm). In case of infectious coryza, subsidence of facial swelling, decrease in serous nasal exudates and purulent ocular discharge, decrease in sneezing and dyspnea were excellent within 5 days of treatment with both Ativet (Acme) and Trimsul 80/400 (DutchFarm), and the recovery rate was 93.3\% and 92\%, respectively. In case of pullorum disease, subsidence of whitish to yellowish diarrhea and reduction of drowsiness were excellent within 4 to 5 days of treatment with both the antibiotics, Enrovet (Acme) and Komibiotril (Komipharm). However, reduction of paleness of comb and wattle was not so excellent within 5 days of treatment. The recovery rate for Enrovet and Komibiotril was 92.5\% and 94.5\%, respectively.
\end{abstract}

Keywords: Sulfadiazine and trimethoprim, infectious coryza, pullorum disease, enrofloxacin, layer birds

\section{INTRODUCTION}

Infectious coryza (IC) is an acute respiratory disease of chickens caused by Avibacterium paragallinarum. The disease occurs worldwide and causes economic losses due to an increased number of culls and a marked (10\% to more than 40\%) drop in egg production, particularly on multi-age farms (Blackall, 1999). The most prominent clinical signs are involvement of nasal passage and sinuses with a serous to mucoid nasal discharge, facial edema, and conjunctivitis (Chauhan, 1996; Swayne et al., 2013). The prevalence is very high in laying hen $(52.8 \%)$ and growing birds (42.8\%) compared to the pre laying stage (16.6\%) (Akter et al., 2013). Various sulfonamides and antibiotics are useful in alleviating the severity and course of IC (Swayne et al., 2013). Potentiated sulfonamide has been reported to the first choice of drug for the treatment of infectious coryza (Sawant et al., 2005). However, a range of new generation antibiotics have been shown to have promise in the treatment of IC (Takahashi et al., 1990; Lublin et al., 1993).

Pullorum disease (PD), caused by Salmonella pullorum, causes heavy death losses in chicks and poults and reduces the productivity of adult birds. The deaths occur mainly during the first 3 weeks after hatching (Swayne et al., 2013). The affected birds can manifest somnolescence, weakness, loss of appetite, poor growth and adherence of chalky white material to the vent (Chauhan, 1996; Swayne et al., 2013). Various sulfonamides followed by nitrofurans and several other antibiotics such as ciprofloxacin, enrofloxacin have been found to be effective in reducing mortality from PD, however, no drug or combination of drugs has been found capable of eliminating infection from a treated flock (Prescott and Dowling, 2013; Swayne et al., 2013). This paper reports the clinical efficacy of potentiated sulfonamides and enrofloxacin in the treatment of infectious coryza and pullorum disease in commercial layer birds respectively.

\section{MATERIALS AND METHODS}

This study was conducted in the Bismillah Poultry Farm and Orkid Poultry Farm, Sreepur, Gazipur during the period from September 2011 to August 2012. The flock size of these two farms was 2000 and 3000, respectively.

*Corresponding e-mail address: taohid@bau.edu.bd 


\section{A. H. Mondal and others}

A total of 300 birds in the Bismillah Poultry Farm were affected with infectious coryza. Diagnosis was made on the basis of clinical signs like swelling of the face and eyes, presence of serous nasal exudates and purulent ocular discharge, sneezing and dyspnoea, and loss of condition due to inappetence, and for confirmation haemagglutination inhibition test was performed. A total of 400 birds in the Orkid Poultry Farm were affected with pullorum disease. Diagnosis was made on the basis clinical signs such as thin yellowish diarrhoea, paleness of comb and wattle, and drowsiness, and the post mortem lesions like necrotic foci on the liver. However, for confirmation serum plate agglutination test using Salmonella pullorum color antigen was performed.

\section{Drugs used}

Trimethoprim $\left(80 \mathrm{mg}\right.$ ) and sulphadiazine $(400 \mathrm{mg})$ : a) Ativet ${ }^{\circledR}$ (Acme Laboratories Ltd., Bangladesh, b) Trimsul ${ }^{\circledR}$ 80/400 oral suspension (DutchFarm, Holland). Enrofloxacin: a) Enrovet ${ }^{\circledR}$ (Acme Laboratories Ltd, Bangladesh), b) Komibiotril (Komipharm ${ }^{\circledR}$, Korea).

\section{Treatment groups}

For infectious coryza, a total of 300 layer birds ( 3 weeks of age) were divided into two groups, namely A ( $\mathrm{n}=$ $150)$ and B $(n=150)$. Birds of group A were treated with Ativet ${ }^{\circ}$ (Acme), and of group B with Timsul ${ }^{\circledR}$ 80/400 oral suspension (DutchFarm) orally through drinking water @ 1 litre/2000 litres of water for 5 days. Pullorum disease affected birds $(2-3$ weeks of age) were divided into two groups, namely $C(n=200)$ and $D(n=200)$. Birds of group C received Enrovet ${ }^{\circledR}$ (Acme) orally through drinking water @ 1 litre/1000 litres water for 5 days while birds of group D were treated with Komibiotril (Komipharm) with same dose and duration. In addition, Respiron and herbal liver tonic were used in both the group. Birds were monitored twice daily to record recovery of clinical signs.

\section{RESULTS AND DISCUSSION}

The efficacy of drugs containing combined preparation of sulfadiazine and trimethoprim against infectious coryza and enrofloxacin against pullorum disease was evaluated on the basis of recovery rate after treatment. However, alleviation of clinical signs at different days of treatment are summarized in Table $1 \& 2$.

Table 1. Comparison in the alleviation of clinical signs between treatment with Ativet and Trimsul 80/400 against infectious coryza in commercial layer birds

\begin{tabular}{|c|c|c|c|c|c|c|c|}
\hline \multirow[t]{2}{*}{ Clinical signs } & \multirow[t]{2}{*}{ Day } & \multicolumn{3}{|c|}{ Ativet } & \multicolumn{3}{|c|}{ Trimsul 80/400 } \\
\hline & & Poor & Good & Excellent & Poor & Good & Excellent \\
\hline \multirow[t]{5}{*}{ Subsidence of facial swelling } & 1 & $\sqrt{ }$ & & & $\sqrt{ }$ & & \\
\hline & 2 & & $\sqrt{ }$ & & & $\sqrt{ }$ & \\
\hline & 3 & & & $\sqrt{ }$ & & $\sqrt{ }$ & \\
\hline & 4 & & & $\sqrt{ }$ & & & $\sqrt{ }$ \\
\hline & 5 & & & $\sqrt{ }$ & & & $\sqrt{ }$ \\
\hline \multirow{5}{*}{$\begin{array}{l}\text { Decrease in serous nasal exudates and } \\
\text { purulent ocular discharge }\end{array}$} & 1 & $\sqrt{ }$ & & & $\sqrt{ }$ & & \\
\hline & 2 & $\sqrt{ }$ & & & $\sqrt{ }$ & & \\
\hline & 3 & & $\sqrt{ }$ & & $\sqrt{ }$ & & \\
\hline & 4 & & $\sqrt{ }$ & & & $\sqrt{ }$ & \\
\hline & 5 & & & $\sqrt{ }$ & & & $\sqrt{ }$ \\
\hline \multirow[t]{5}{*}{ Decrease in sneezing and dyspnoea } & 1 & $\sqrt{ }$ & & & $\sqrt{ }$ & & \\
\hline & 2 & $\sqrt{ }$ & & & $\sqrt{ }$ & & \\
\hline & 3 & & $\sqrt{ }$ & & $\sqrt{ }$ & & \\
\hline & 4 & & $\sqrt{ }$ & & & $\sqrt{ }$ & \\
\hline & 5 & & & $\sqrt{ }$ & & & $\sqrt{ }$ \\
\hline \multirow[t]{5}{*}{ Appetite } & 1 & $\sqrt{ }$ & & & $\sqrt{ }$ & & \\
\hline & 2 & $\sqrt{ }$ & & & $\sqrt{ }$ & & \\
\hline & 3 & & $\sqrt{ }$ & & & $\sqrt{ }$ & \\
\hline & 4 & & $\sqrt{ }$ & & & $\sqrt{ }$ & \\
\hline & 5 & & $\sqrt{ }$ & & & $\sqrt{ }$ & \\
\hline
\end{tabular}


Table 2. Comparison in the alleviation of clinical signs between treatment with Enrovet and Komibiotril against pullorum disease in commercial layer birds

\begin{tabular}{|c|c|c|c|c|c|c|c|}
\hline \multirow[t]{2}{*}{ Clinical signs } & \multirow[t]{2}{*}{ Day } & \multicolumn{3}{|c|}{ Enrovet } & \multicolumn{3}{|c|}{ Komibiotril } \\
\hline & & Poor & Good & Excellent & Poor & Good & Excellent \\
\hline \multirow{5}{*}{$\begin{array}{l}\text { Subsidence of thin whitish to yellowish } \\
\text { diarrhoea }\end{array}$} & 1 & $\sqrt{ }$ & & & $\sqrt{ }$ & & \\
\hline & 2 & & $\sqrt{ }$ & & $\sqrt{ }$ & & \\
\hline & 3 & & $\sqrt{ }$ & & & $\sqrt{ }$ & \\
\hline & 4 & & & $\sqrt{ }$ & & & $\sqrt{ }$ \\
\hline & 5 & & & $\sqrt{ }$ & & & $\sqrt{ }$ \\
\hline \multirow[t]{5}{*}{ Reduction of paleness of comb and wattle } & 1 & $\sqrt{ }$ & & & $\sqrt{ }$ & & \\
\hline & 2 & $\sqrt{ }$ & & & $\sqrt{ }$ & & \\
\hline & 3 & & $\sqrt{ }$ & & & $\sqrt{ }$ & \\
\hline & 4 & & $\sqrt{ }$ & & & $\sqrt{ }$ & \\
\hline & 5 & & & $\sqrt{ }$ & & $\sqrt{ }$ & \\
\hline \multirow[t]{5}{*}{ Reduction of drowsiness } & 1 & $\sqrt{ }$ & & & $\sqrt{ }$ & & \\
\hline & 2 & $\sqrt{ }$ & & & $\sqrt{ }$ & & \\
\hline & 3 & & $\sqrt{ }$ & & & $\sqrt{ }$ & \\
\hline & 4 & & $\sqrt{ }$ & & & & $\sqrt{ }$ \\
\hline & 5 & & & $\sqrt{ }$ & & & $\sqrt{ }$ \\
\hline
\end{tabular}

Treatment of infectious coryza with Ativet ${ }^{\circledR}$ (Acme) and Trimsul® 80/400 (DutchFarm) showed that 93.3\% and $92 \%$ birds were completely recovered after treatment (Table 3). The present trial demonstrated that the efficacy of Ativet ${ }^{\circledR}$ was almost similar with the Trimsul ${ }^{\circledR}$ 80/400. The present finding of higher efficacy of Ativet® (Acme) and Trimsul (DutchFarm) is discordant with the earlier report (Nonga et al., 2010) who reported $25 \%$ efficacy of potentiated sulfonamide against infectious coryza. However, it supports the report of Prescott and Dowling (2013) who reported that potentiated sulfonamide is effective against infectious coryza.

Table 3. Efficacy of Ativet ${ }^{\circledR}$ and Trimsul ${ }^{\circledR} 80 / 400$ against infectious coryza in commercial layer birds

\begin{tabular}{ccccc}
\hline Name of disease & Drugs & No. of birds treated & No. of birds recovered & Recovery rate $(\%)$ \\
\hline Infectious coryza & Ativet ${ }^{\circledR}$ & 150 & 140 & 93.3 \\
& Trimsul ${ }^{\circledR} 80 / 400$ & 150 & 138 & 92.0 \\
\hline
\end{tabular}

Table 4. Efficacy of Enrovet ${ }^{\circledR}$ and Komibiotril $®$ for the treatment of pullorum disease in commercial layer birds

\begin{tabular}{ccccc}
\hline Name of disease & Drugs & No. of birds treated & No. of birds recovered & Recovery rate $(\%)$ \\
\hline Pullorum disease & Enrovet ${ }^{\circ}$ & 200 & 185 & 92.5 \\
& Komibiotril ${ }^{\circ}$ & 200 & 189 & 94.5 \\
\hline
\end{tabular}

Treatment of pullorum disease in commercial layer birds with two commercial preparations of enrofloxacin (Enrovet ${ }^{\circledR}$, Acme and Komibiotril ${ }^{\circledR}$, Korea) revealed that $92.5 \%$ birds recovered following treatment with Enrovet ${ }^{\circledR}$ (Acme) and $94.5 \%$ recovered after treatment with Komibiotril ${ }^{\circledR}$ (Korea) (Table 4). Both the commercial preparations of enrofloxacin showed similar efficacy in the treatment of pullorum disease in layer birds. A number of antibiotics are reported to be effective in the treatment of pullorum disease such as flumequine, ciprofloxacin, enrofloxacin, oxytetracycline, potentiated sulfonamides. Here in this study excellent efficacy of enrofloxacin (Enrovet and Komibiotril) for the treatment of pullorum disease is in agreement with earlier reports (Chauhan, 1996; Gbylik-Sikorska et al., 2013; Prescott and Dowling, 2013; Swayne et al., 2013). 


\section{A. H. Mondal and others}

\section{REFERENCES}

1. Akter MR, Khan MR, Rahman MM, Khan MS and Kabir SL (2013). Investigation on infectious coryza of layer chicken in Bangladesh with isolation, identification and antibiogram study. Scientific Journal of Veterinary Advances 1: 83-89.

2. Blackall P (1999). Infectious coryza: overview of the disease and new diagnostic options. Clinical Microbiology Reviews 12: 627-632.

3. Chauhan H (1996). Poultry diseases, diagnosis and treatment. edn. New Age International.

4. Gbylik-Sikorska M, Posyniak A, Gajda A and Błądek T (2013). Determinaton of enrofloxacin and ciprofloxacin in albumin and freeze-dried-eggs by liquid chromatography with fluorescence detection. Bulletin of the Veterinary Institute in Pulawy 57: 351-355.

5. Lublin A, Mechani S, Malkinson M and Weisman Y (1993). Efficacy of norfloxacin nicotinate treatment of broiler breeders against Haemophilus paragallinarum. Avian Diseases 37: 673-679.

6. Nonga H, Simon C, Karimuribo E and Mdegela R (2010). Assessment of antimicrobial usage and residues in commercial chicken eggs from smallholder poultry keepers in Morogoro municipality, Tanzania. Zoonoses and Public Health 57: 339-344.

7. Prescott JF and Dowling PM (2013). Antimicrobial Therapy in Veterinary Medicine. $5^{\text {th }}$ edn., John Wiley \& Sons.

8. Sawant A, Sordillo L and Jayarao B (2005). A survey on antibiotic usage in dairy herds in Pennsylvania. Journal of Dairy Science 88: 2991-2999.

9. Swayne DE, Glisson JR, McDougald LR, Nolan LK, Suarez DL and Nair VL (2013). Diseases of Poultry. $13^{\text {th }}$ edn. John Wiley \& Sons.

10. Takahashi I, Yoshida T, Honma Y and Saito E (1990). Comparison of the susceptibility of Haemophilus paragallinarum to ofloxacin and other existing antimicrobial agents. Journal of the Japan Veterinary Medical Association 43: 187-191. 